\title{
PENAMBAHAN AMPAS TEH HIJAU FERMENTASI DI DALAM RANSUM SERTA PENGARUHNYA TERHADAP LAJU PERTUMBUHAN ITIK CIHATEUP
}

\section{THE ADDITION OF FERMENTED GREEN TEA WASTE IN RATION AND ITS EFFECT TO GROWTH RATE OF CIHATEUP DUCKS}

\author{
A Kusmayadi1a \\ 1Jurusan Peternakan Fakultas Pertanian Universitas Perjuangan Jl. Pembela Tanah Air 177, Tawang, \\ Tasikmalaya \\ aKorespondensi: Andri Kusmayadi, E-mail: andrikusmayadi@unper.ac.id
}

(Received: 05-07-2020; Accepted: 05-10-2020)

\begin{abstract}
The growth of local ducks is relatively slow but its availability in daily life is very much needed to support the intake of animal protein from the community. Feeding that contains natural antioxidants from plants is believed to improve the growth of poultry. Green tea waste is reported to contain high antioxidant compounds that are beneficial to the body but contains tannin compounds whose presence can interfere with digestion. Processing methods of green tea waste are needed to reduce the antinutrient compounds, one of which is by fermentation. The research aims to determine the effect of the addition of fermented green tea waste to the growth rate of Cihateup ducks. The study used 60 Cihateup ducks which were grouped into 4 treatment groups containing 0, 1, 2 and 3\% fermented green tea waste, respectively. Ducks are maintained for 8 weeks to observe the growth rate. The results showed that the addition of fermented green tea waste in the feed significantly affected the growth rate of ducks. The addition of fermented green tea waste at the level of $1 \%$ has a positive impact on the growth rate.
\end{abstract}

Keyword: green tea waste, fermentation, ducks, growth rate.

\begin{abstract}
ABSTRAK
Pertumbuhan itik lokal relatif lambat namun ketersediaannya dalam kehidupan sehari-hari sangat diperlukan untuk menunjang sumber protein hewani masyarakat. Pemberian pakan tambahan yang berasal dari herbal diyakini mampu memperbaiki pertumbuhan unggas. Ampas teh hijau dilaporkan mengandung senyawa antioksidan tinggi yang baik bagi tubuh namun mengandung senyawa tannin yang keberadaannya dapat mengganggu kecernaan. Diperlukan metode pengolahan pada ampas teh hijau untuk mengurangi senyawa antinutrisi tersebut melalui proses fermentasi. Penelitian bertujuan untuk mengetahui pengaruh penambahan ampas teh hijau fermentasi terhadap laju pertumbuhan itik Cihateup. Penelitian menggunakan 60 ekor itik Cihateup yang telah dikelompokkan ke dalam 4 kelompok perlakuan pakan yang mengandung ampas teh hijau fermentasi masing-masing sebanyak 0, 1, 2 dan 3\%. Itik dipelihara selama 8 minggu untuk diamati laju pertumbuhannya. Hasil penelitian menunjukkan level penambahan ampas teh hijau fermentasi dalam pakan berpengaruh nyata terhadap laju pertumbuhan itik. Penambahan ampas teh hijau fermentasi pada level $1 \%$ memberikan dampak positif terhadap laju pertumbuhan.
\end{abstract}

Kata kunci: ampas teh hijau, fermentasi, itik, laju pertumbuhan.

A Kusmayadi. 2020. Penambahan Ampas Teh Hijau Fermentasi Di Dalam Ransum Serta Pengaruhnya Terhadap Laju Pertumbuhan Itik Cihateup . Jurnal Peternakan Nusantara 6(2): 6368. 


\section{PENDAHULUAN}

Teh hijau dilaporkan memiliki aktivitas antioksidan yang sangat kuat sampai 100 kali lipat lebih efektif dibandingkan Vitamin $\mathrm{C}$ dan 25 kali lebih tinggi dibandingkan dengan Vitamin E (Yusni et al 2015). Golongan senyawa polifenol pada teh hijau terdiri atas flavonoid, flavanol dan asam fenolat yang dilaporkan memiliki manfaat yang baik bagi tubuh seperti antioksidan dan anti stress oksidatif (Yan et al. 2020). Anjarsari (2016) menambahkan bahwa salah satu senyawa yang paling penting dari teh hijau yaitu adanya katekin yang merupakan antioksidan alami tertinggi yang memiliki peranan penting dalam mekanisme aktivitas antioksidan pada teh hijau. Kandungan katekin pada daun teh berkisar antara 20 - 30\% bahan kering sehingga teh dapat dikategorikan sebagai minuman fungsional.

Ampas teh merupakan limbah industri pembuatan teh kemasan yang dapat dijadikan sebagai alternatif imbuhan pakan atau bahan baku pakan ternak dengan kandungan protein mencapai 27,42\% (Krisnan 2005). Ketersediaan ampas teh cukup melimpah dimana setiap tahunnya dapat mencapai 166.000 ton dan sebagian besar belum dimanfaatkan (Saqifah et al. 2010; Handayani et al. 2014). Ampas teh berpotensi dimanfaatkan sebagai alternatif imbuhan pakan pada unggas namun memiliki antinutrisi yaitu tingginya serat kasar, tannin dan saponin sehingga perlu dilakukan fermentasi agar kualitasnya lebih baik sehingga mudah dicerna oleh unggas (Tugiyanti et al. 2017). Berbagai Teknik fermentasi telah dilakukan untuk menurunkan antinutrisi pada ampas teh, salah satunya menggunakan Effective Microorganism (EM4) yang dapat menurunkan kadar serat kasar pada kulit pisang (Triani. 2017) dan kadar tannin pada Azolla microphylla (Melita et al. 2018).

Penelitian mengenai penambahan ampas teh fermentasi telah diuji pada puyuh pejantan berdasarkan bentuk teh yang difermentasinya seperti ampas teh serbuk, ampas teh butiran dan ampas daun teh (Utami et al 2018). Penelitian ini menggunakan semua bagian ampas teh hijau yang difermentasi sebagai imbuhan itik Cihateup. Penelitian bertujuan untuk mengetahui pengaruh penambahan ampas teh hijau fermentasi terhadap laju pertumbuhan itik Cihateup.

\section{MATERI DAN METODE}

\section{Materi}

Itik Cihateup berjenis kelamin jantan, ampas teh hijau, fermentor EM4, pakan basal, air minum, mineral, vitamin, tempat pakan dan tempat minum, plastik, label dan timbangan

\section{Perlakuan}

Penelitian dilakukan dengan cara mengamati laju pertumbuhan itik Cihateup pada 4 kelompok perlakuan pakan (A1 - A4) yaitu masing-masing mengandung ampas teh hijau fermentasi sebanyak $0 \%, 1 \%, 2 \%$ dan $3 \%$.

\section{Rancangan Percobaan}

Data dianalisis menggunakan sidik ragam menggunakan Rancangan Acak Lengkap (RAL) (Gasperz 1991) dengan bantuan perangkat lunak SPSS 25.0.

\section{Peubah yang Diamati}

Peubah yang diamati yaitu laju pertumbuhan itik Cihateup. Laju pertumbuhan itik diukur dengan cara menimbang bobot badan itik mulai 0 minggu sampai 8 minggu yang ditimbang setiap minggunya.

\section{Prosedur Pelaksanaan}

Ampas teh hijau yang didapatkan dari Kecamatan Taraju, Tasikmalaya, difermentasi menggunakan EM4 secara anaerob selama 7 hari pada suhu ruang. Produk hasil fermentasi dicampurkan ke dalam ransum itik Cihateup yang telah dikelompokkan ke dalam 4 kelompok perlakuan yaitu $0 \%, 1 \%, 2 \%$ dan 3\% (A1 - A4). Itik dipelihara selama 8 minggu untuk diamati laju pertumbuhannya.

\section{HASIL DAN PEMBAHASAN}

Hasil uji laju pertumbuhan itik Cihateup yang disuplementasi dengan ampas teh hijau fermentasi disajikan pada Gambar 1. 

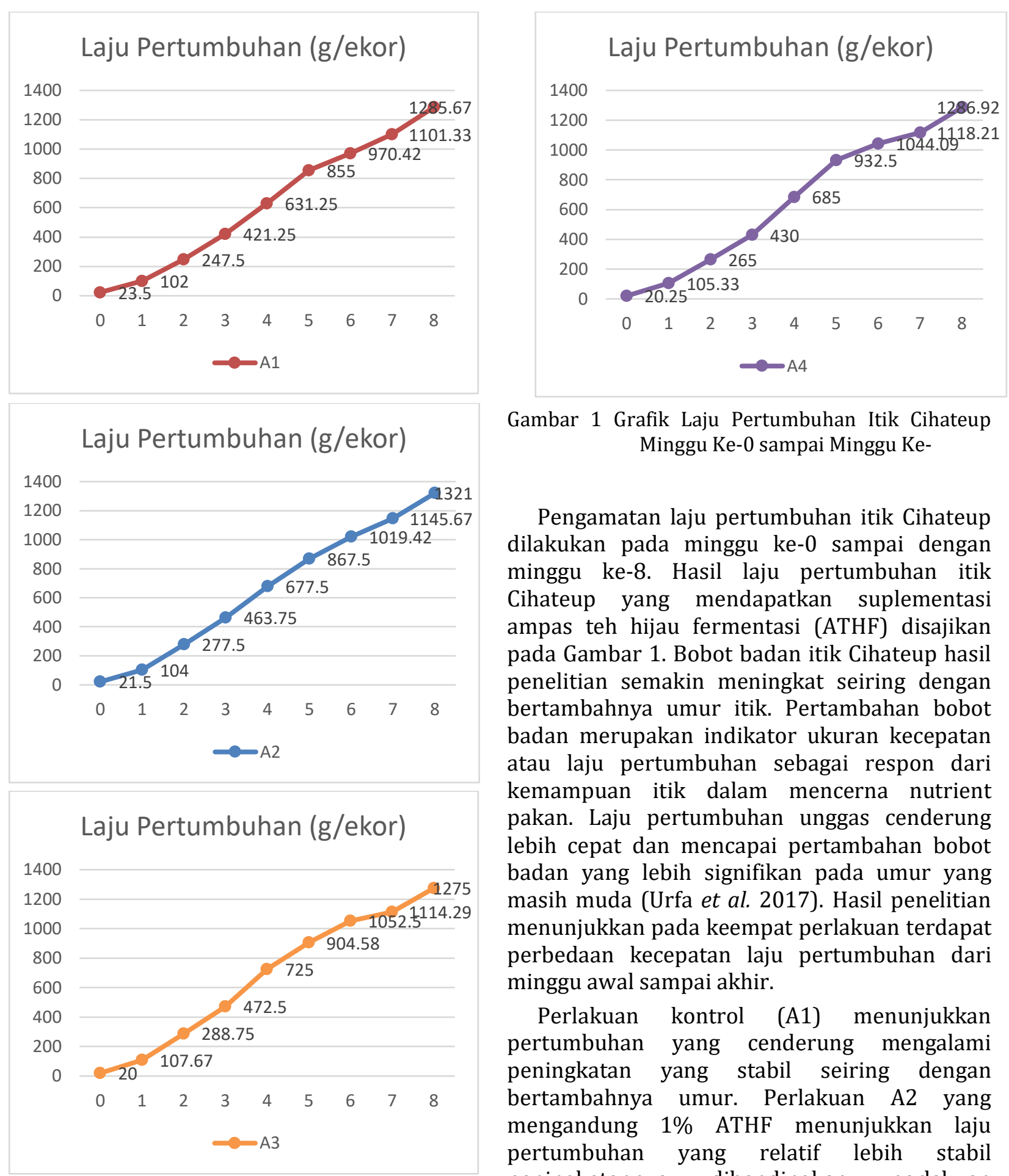

Gambar 1 Grafik Laju Pertumbuhan Itik Cihateup Minggu Ke-0 sampai Minggu Ke-

Pengamatan laju pertumbuhan itik Cihateup dilakukan pada minggu ke-0 sampai dengan minggu ke-8. Hasil laju pertumbuhan itik Cihateup yang mendapatkan suplementasi ampas teh hijau fermentasi (ATHF) disajikan pada Gambar 1. Bobot badan itik Cihateup hasil penelitian semakin meningkat seiring dengan bertambahnya umur itik. Pertambahan bobot badan merupakan indikator ukuran kecepatan atau laju pertumbuhan sebagai respon dari kemampuan itik dalam mencerna nutrient pakan. Laju pertumbuhan unggas cenderung lebih cepat dan mencapai pertambahan bobot badan yang lebih signifikan pada umur yang masih muda (Urfa et al. 2017). Hasil penelitian menunjukkan pada keempat perlakuan terdapat perbedaan kecepatan laju pertumbuhan dari minggu awal sampai akhir.

Perlakuan kontrol (A1) menunjukkan pertumbuhan yang cenderung mengalami peningkatan yang stabil seiring dengan bertambahnya umur. Perlakuan A2 yang mengandung $1 \%$ ATHF menunjukkan laju pertumbuhan yang relatif lebih stabil peningkatannya dibandingkan perlakuan lainnya (Gambar 1). Hal ini disebabkan perlakuan A2 mengandung senyawa polifenol pada level optimal dibandingkan perlakuan A3 dan A4 yang mengandung dosis ATHF yang lebih tinggi. Yan et al. (2020) melaporkan bahwa senyawa polifenol memiliki mekanisme aktivitas antioksidan yang baik dengan cara mencegah radikal bebas yaitu molekul yang sangat aktif yang dapat mengganggu fungsi fisiologi dan patologis pada ternak. Salah satu dampak senyawa polifenol pada tubuh yaitu dapat meningkatkan kadar katalase serum 
(CAT), glutation peroksidase (GSH-Px) dan superoksida dismutase (SOD) serta menurunkan produksi malondialdehid (MDA). Dengan demikian, ternak yang mendapatkan suplementasi senyawa polifenol pada level yang optimal dapat terhindar dari stress sehingga laju pertumbuhan berjalan dengan baik. Perlakuan A3 dan A4 diduga mengandung senyawa polifenol dalam jumlah yang lebih tinggi (melebihi dosis optimal) sehingga bersifat prooksidan bagi tubuh (Yordi et al. 2012).

Laju pertumbuhan dan pencapaian bobot badan itik yang sesuai dengan umur diperlukan evaluasi dari hasil pemeliharaan sehingga diperoleh efisiensi produksi dan memudahkan manajemen produksi berikutnya. Pertambahan bobot badan itik yang berbeda pada setiap perlakuan dipengaruhi oleh pertambahan bobot badan pada minggu sebelumnya, iklim, kandungan nutrisi dan jumlah konsumsi ransum (Kholik et al, 2019). Hasil penelitian pada Gambar 1. menunjukkan bahwa laju pertumbuhan itik semakin meningkat seiring bertambahnya umur dan belum menunjukkan pertumbuhan yang melambat sehingga belum membentuk kurva sigmoid. Kurva sigmoid terbentuk ketika pertumbuhan unggas meningkat sampai titik infleksi tertentu sehingga menyerupai huruf ' $\mathrm{S}$ '. Tazkia dan Anggraeni (2009) melaporkan bahwa laju pertumbuhan ternak akan mengalami perlambatan setelah mengalami pubertas atau titik infleksi. Hal ini disebabkan oleh waktu pemeliharaan yang cenderung singkat pada penelitian ini yaitu hanya sampai pada minggu ke-8 (hari ke-56). Sementara kurva pertumbuhan yang berbentuk sigmoid pada itik Alabio dihasilkan sampai umur 16 minggu (Susanti dan Prasetyo, 2007; Yusinta et al, 2017).

Pola pertumbuhan itik sebagaimana pertumbuhan unggas secara umum dibagi menjadi dua fase pertumbuhan yaitu fase akselerasi (proses pertumbuhan yang cepat dengan laju pertumbuhan tinggi) dan fase retardasi (proses penurunan laju pertumbuhan). Pola pertumbuhan unggas akan membentuk kurva pertumbuhan berbentuk sigmoid sebagai cerminan kemampuan ternak dalam menampilkan potensi genetik dan perkembangan bagian tubuh sampai ternak tersebut dewasa. Kurva pertumbuhan dapat menggambarkan kapan terjadinya periode pertumbuhan unggas yang cepat atau lambat serta titik infleksinya sehingga dapat mengetahui optimalisasi pertumbuhannya dan menentukan waktu panen yang tepat untuk mendapatkan keuntungan maksimal (Hafez dan Dyer 1969; Urfa et al. 2017).

\section{KESIMPULAN DAN IMPLIKASI}

\section{Kesimpulan}

Ampas teh hijau fermentasi pada level 1\% mampu memperbaiki laju pertumbuhan itik Cihateup dibandingkan perlakuan lainnya.

\section{Implikasi}

Penggunaan ampas teh hijau fermentasi sampai level 3\% sebagai pakan tambahan pada itik Cihateup dapat memperbaiki laju pertumbuhan. Penerapan ampas teh hijau sebagai bahan pakan dapat mendayagunakan limbah industri pengolahan teh, serta pengolahannya melalui teknologi fermentasi dapat menurunkan kandungan antinutrisinya.

\section{DAFTAR PUSTAKA}

Anjarsari IRD. 2016. Katekin teh Indonesia : prospek dan manfaatnya. Jurnal Kultivasi, 15(2): $99-106$.

Gaspersz, 1991. Teknik Analisis dalam Penelitian Percobaan. Tarsito: Bandung

Hafez ESE, Dyer IA. 1969. Animal Growth and Nutrition. Lee \& Febiger. Philadelphia.

Handayani D, Mun'im A., Ransi AS. 2014. Optimation of green tea waste axtraction using microwave assisted extraction to yield green tea extract. Trad. Med. J., 19(1): 29 - 35.

Kholik A, Indrijani H, Tanwiriah,W. 2019. Model kurva pertumbuhan ayam super garut yang diberi tepung pasak bumi (Euricoma longifolia Jack) dalam ransum. Jurnal Ilmu Ternak, 19(1): $69-77$.

Krisnan R. 2005. Pengaruh pemberian ampas teh (Camellia Sinensis) fermentasi dengan Aspergillus niger pada ayam broiler. JITV, 10(1): 1-5.

Melita SN, Muryani R, Mangisah I. 2018. The effect of azolla microphylla fermented powder in the diet to use protein of 
crossbreed native chicken. Jurnal Peternakan Indonesia, 20(1): 8 - 14.

Saqifah N, Purbowati E, Rianto E. 2010. Pengaruh ampas teh dalam pakan konsentrat terhadap konsentrasi VFA dan NH3 cairan rumen untuk mendukung pertumbuhan sapi peranakan Ongole. Prosiding Seminar Nasional Teknologi Peternakan dan Veteriner: 205-210.

Susanti T, Prasetyo LH. 2007. Model regresi pertumbuhan dua generasi populasi ternak terseleksi itik Alabio. JITV. 12(4) : 300-304.

Tazkia R, Anggraeni A. 2009. Pola dan estimasi kurva pertumbuhan sapi Friesian Holstein di wilayah kerja bagian timur KPSBU Lembang. Prosiding Seminar Nasional Teknologi Peternakan dan Veteriner. Bogor, 13 - 14 Agustus 2009. Hal 121-135.

Triani HD. 2017. Pengaruh pemberian biji alpukat dan kulit pisang fermentasi terhadap berat serta warna kuning telur puyuh. Jurnal Bibiet, 2(2): 60 - 67.

Tugiyanti E, Susanti E, Sulistyawan IH. 2017. Pemanfaatan ampas teh sebagai feed aditif pakan unggas dan anti bakteri terhadap Escherichia coli. Prosiding Seminar Teknologi dan Agribisnis Peternakan V: Teknologi dan Agribisnis Peternakan untuk Mendukung Ketahanan Pangan, Fakultas Peternakan Universitas Jenderal Soedirman, Purwokerto, 18 November 2017: $54-62$.

Urfa S, Indrijani H, Tanwiriah W. 2017. Model kurva pertumbuhan ayam kampung unggul balitnak (KUB) umur 0-12 minggu. Jurnal Ilmu Ternak, 17(1): 59 - 66.

Utami TS, Sulistyawan IH, Tugiyanti E. 2018. Supplementation of fermented tea waste in diets on final body weight and carcass percentage of male quails. Journal of Livestock and Animal Production. 1(1): 48 53.

Yan Z, Zhong Y, Duan Y, Chen Q, Li F. 2020. Antioxidant mechanism of tea polyphenols and its impact on health benefits. Animal Nutrition, 6: 115 - 123.

Yordi EG, Perez EM, Matos MJ, Villares EU. 2012. Antioxidant and pro-oxidant effects of polyphenolic compounds and structureactivity relationship evidence. In Nutrition, Well-Being and Health, 2 - 48. InTech Publisher.

Yusinta AN, Kurnianto E, Sutopo S. 2017. Analisis parameter pertumbuhan itik Magelang generasi ketiga di Balai Pembibitan Ternak Non Ruminansia Satuan Kerja Itik Banyubiru. Jurnal Ilmu-Ilmu Peternakan, 27(2): $44-53$.

Yusni Y, Teuku HTR, Achmad TH. 2015. Aktivitas polifenol teh hijau (Camellia sinensis (L) 0 . Kuntze) sebagai imunomodulator melalui respons supresi imunoglobulin E (IgE) pada rinitis alergika. $M K B, 47(3): 160$ - 166. 
